\title{
14 \\ GLOBAL FOOD SECURITY, POPULATION AND LIMITS TO GROWTH
}

COLIN D. BUTLER

\section{Abstract}

Egalitarians have long called for a fairer global distribution of the determinants of health and nutrition. But the progress made towards global health for all, especially between 1960 and 1990 is now faltering, though some emerging technologies and social movements may still have the potential to reverse this trend. This chapter will argue that the struggle for global development is placed at risk by insufficient high-level recognition of the nexus between emerging 'limits to growth' manifested by high energy prices, climate change and the diversion of food crops to fuel. These, with other issues, such as inequality, neoliberalism, and the general refusal of the West to accept its role in the genesis for the 'War on Terror' have profound implications for human well-being that are immensely troubling over the next few decades and beyond.

The most important academic response that is needed to cope with these interlinked crises, including for food security, is not to call for more agricultural investment or for better technology (until recently the main mantras), but for genuine, multidisciplinary appreciation of the interlinked, systemic, nature of these problems. Together with increased food production, humanity has also to slow population growth by improving human rights-based determinants of lower fertility, especially better education for girls.

In fact, it can be argued that the moral compass of the global elite, largely based in the West, supported and corrupted by lobbyists, has, in recent decades, been set to excessive consumerism during the neoliberalism-fuelled 'cornucopian enchantment'. Some might suggest that it has always been thus, but the reduction in inequality between the end of World War II and the ascent of neoliberalism was for several decades complemented by aspirational 
language of health and food for all. This recent decay in morality and global responsibility has influenced government and academia in ways that disguise awareness of these larger risks. Its continuation will lead to the managed retreat of civilisation, or disorderly rout. Urgent reform is thus needed.

\section{Introduction: Nutrition, Hunger, Famine and Their 'Eco-social' Determinants}

This latest Lancet Series concludes, not surprisingly perhaps, that the international nutrition system is broken. (Horton, 2008)

This chapter has a very broad scope. Lack of space prevents in-depth discussion of many issues it raises; I can thus only give impressions. From the argument that causation is rarely purely ecological or social, the chapter ranges to the Green Revolution, hunger targets and measures, and how impinging limits to growth threaten the attainment of hunger targets. It also touches on neoliberalism and the follies of conventional economists.

Good nutrition is essential for health, both at the individual and population levels. Many health determinants are social, such as inequality and companionship, but many products of social factors manifest physically. Too often, the public health literature in recent decades has been biased towards social causal factors (Butler and Friel, 2006, McMichael et al., 2015). Even more deficient, however, is the failure of academics and politicians (though not the military) to sufficiently consider the interaction of social with physical (including environmental) determinants, such as has very plausibly contributed to the current Syrian conflict (Kelly et al., 2015). This leads to oversimplification and to inadequate remedies.

One such example of 'either/or' thinking is to consider the causes of food distribution and famine. Nutritional causation is not binary; that is, it is neither purely social (as extreme interpretations of Amartya Sen's work might suggest) nor is it purely environmental (as an extreme interpretation of Lester Brown or Paul Ehrlich's work might suggest) (e.g. Ehrlich, 1968; Brown, 2011).

Even overnutrition (another form of malnutrition) has ecological as well as social causes; for example, cheap, nutrient-poor calorie - rich food (such as corn syrup) is grown and stored more easily and, consequently, is more abundant than many more nutritious alternatives (e.g. raspberries). All food is derived from the environment, whether gathered or hunted from the wild, cultivated from the soil, raised via animal (including fish) farming, or even through hydroponics. 
Food is not produced from ideas alone, though of course ingenuity can increase food production. Laboratory produced meat remains a research project, though insect farming, which of course also depends on the environment, is increasing.

Food availability and consumption, together with its ingestion and absorption, are shaped by a myriad of social elements, but environmental factors (including the cost of energy, the supply of phosphorus and a sufficiently favourable climate) are always involved. If food supplies were to fail due to drought or some other catastrophe (e.g. war or volcanic activity, as happened globally after the explosion of Mount Tambora, leading to the Year Without a Summer in 1816 (Wood, 2014)), and if the failure is sufficiently widespread or prolonged so that trade or aid cannot fully compensate, then population nutrition must suffer.

Beyond a threshold of scarcity, redistribution fails, by definition. That is, redistribution can successfully prevent crises, but extremes exist beyond which redistribution is not enough. Redistribution can also be more difficult to implement if at times of approaching crisis, elites capture dwindling supplies, restricting sharing (Motesharrei et al., 2014). A recent historical example is the Rwandan genocide of 1994. While there was little frank starvation preceding the genocide, there was great scarcity (especially of arable land), marked inequality and the apprehension that scarcity would deepen (André and Platteau, 1998; Butler, 2000a). Other examples are of the Russian and French revolutions, each of which was driven - but not exclusively, by extreme social inequality. ${ }^{1}$

\section{Macronutrient insufficiency and the 'Green' Revolution}

In developed countries, most nutritional attention is focused on the search for elixirs to maximise healthy life (such as a putative optimal balance of micronutrients) and the avoidance of overnutrition and obesity. Undernutrition also occurs (and is increasing), but is generally restricted to micronutrient deficiencies among the extremely poor; some of whom are homeless, some of whom suffer chronic alcoholism and many of whom have untreated mental illness.

In contrast, in developing countries, undernutrition of 'macronutrients' (carbohydrates, fat and protein, vital for energy and amino acids, the building blocks of protein) are important problems, no more so in absolute terms than in the world's second most populous nation, India. In 2012, the Food and Agricultural Organization (FAO) of the UN estimated that 48 per cent of

1 A strong El Niño may have contributed to poor harvests leading to the French revolution (Grove, 1998). 
Indian children were stunted (FAO, 2012). This represents an enormous loss of human potential. More people (287 million) were reported as undernourished between 2010 and 2012 in South Asia than in sub-Saharan Africa (234 million) (FAO, 2012).

The 'Green Revolution' expanded total food production greatly, including on the Indian sub-continent. However, in India, extreme inequality is ancient, illustrated by its still-entrenched caste system, described in 2006 by then Indian Prime Minister Singh as a human rights scourge worse than apartheid was in South Africa (Rahman, 2006). Indian-born Nobel Laureate economist, Amartya Sen, is renowned for his work on 'effective' food 'entitlement', which he defines as the capacity to acquire food by cultivation or purchase. ${ }^{2}$ His most famous book on this topic, published in 1981, arose, in part, from his childhood experience in Calcutta (now Kolkata), during World War II (Sen, 1981). Put simply, the year of maximum famine (1943) was not the year of minimum food production (1941). Social factors clearly played a role.

A lesser-known famine in North Vietnam, also in World War II, killed a similar number of people to that in Bengal (Gunn, 2011). Unlike in India, and ignoring deep underlying factors of resource competition that contributed to Japanese aggression in World War II, this famine can be considered entirely of social origin, due to the forced acquisition of locally grown food by the occupying Japanese. The horrific famine in China, from 1958 to 1962, was predominantly caused socially, as was the Ukrainian famine in the 1920s. But the social dimension to these famines (and revolutions) does not mean there is no environmental component; this implies that we should not exclusively rely on social factors to prevent all future famine and revolution. We need to also consider environmental resources.

\section{The Measurement of Global Hunger: A Black Art?}

In 1996, at the World Food Summit, an ambitious target was announced to halve macronutrient hunger by 2015, from 850 to 425 million. Only four years later this target was amended, making it easier, as part of the first Millennium

\footnotetext{
2 'Starvation is ... some people not having enough food to eat. It is not the characteristic of there being not enough food to eat. While the latter can be a cause of the former, it is but one of many possible causes' (Sen, 1981, p. 1). His insight is not unique. Mallory (1926) wrote, 'There are some famines that are due almost certainly to "natural" causes (i.e. drought, locusts, plant disease), and there are scarcely any to which natural phenomena do not contribute.' This implies that Mallory recognised that the cause of famines was not exclusively environmental.
} 
Development Goal (MDG) (Pogge, 2004). The revised target (about 570 million depending on assumptions of global population in 2015) permitted almost 150 million people more to remain hungry (see Figure 14.1).

Since 1999, the FAO has produced an annual report called The State of Food Insecurity in the World (SOFI), which is widely regarded as the most authoritative source of global hunger data. In response to growing criticism, SOFI 2012 (FAO, 2012) reported new global hunger data for the period from 1990 (see Figure 14.1). Without comment, explanation or criticism, the FAO in this report also redefined a target of the Millennium Development Goal for hunger (see Box 14.1). This error was subsequently corrected in later reports, with no acknowledgement of the 2012 mistake.

However, the main reason for the revision in data is that, since 2012, the FAO has also used a new measurement and definition of hunger. This has been criticised for using, in part, a caloric intake threshold, lasting for more than a year, at a level below that required for a sedentary lifestyle (Lappé et al., 2013). However, in defence of the FAO, this is only one component of a new, complex assessment of hunger that also reflects population nutrition using median height as a composite indicator of the interaction between calorie ingestion, absorption, energy output and metabolism. I think it is too early to judge the success of this measure, but it is nevertheless puzzling how hunger could be found to have fallen in recent years at the same time as food prices, adjusted for inflation, have risen so much (Butler, 2015). Until the 2012 FAO revision, this hunger target looked hopelessly beyond reach; but it can only be considered a modest failure. The second revised target of 700 million is only 152 million fewer than the revised number of hungry in 2010. In other words, it is not badly out of reach (if the new numbers are accepted).

\section{Repositioning the Hunger Targets}

Even less well recognised, but consistent with the perhaps excessive optimism that surrounds the topic of global hunger, is that limits to growth (see Box 14.2) are combining with inequality to reawaken the curse of famine. Old and 'sleeping' infectious disease scourges (e.g. plague, tuberculosis) could return in future if population-level immunity is weakened by worse nutrition due to rising food prices and increased social disorganisation (Butler, 2012). In combination with this is the risk of harm from human groups behaving essentially as predators, attacking those who are weaker and vulnerable (Motesharrei et al., 2014). 
Adequate responses by government and public health authorities are also being eroded, as is now evident in parts of sub-Saharan Africa and South Asia. For example, the recent famine in a large part of Somalia was worsened by the extreme Islamist group, Al Shabaab, who targeted relief workers (Maxwell et al., 2012).

\section{Box 14.1 The FAO's inadvertent and brief redefinition of the MDG hunger target.}

Part of the first Millennium Development Goal (MDG) target is 'to halve the proportion of people who suffer from hunger between 1990 and 2015'. But in 2012, the FAO reported this as to 'halve the prevalence of under-nourishment in the developing world by 2015'. Partly because of this revision, the FAO also concluded that the MDG target was 'within reach' (FAO, 2012). However, a far more important reason for this conclusion was that the estimate of hunger in 1990 was revised upwards from 850 million to over one billion, and that for years after 2000 it was lowered (Butler, 2015). Consequently, using these revised data, the MDG target requires a fall between 2013 and the end of 2015 of less than 120 million; prior to the revisions, the required decline was 340 million (see Figure 14.1).

Estimates of hunger assembled by the FAO, based on surveys, have long been criticised, but, at the moment, remain dominant. Barrett (2013) and others have argued that there are inadequate resources (financial and/or political) to conduct sufficient high-quality surveys to measure hunger in developing countries accurately. It seems clear that these hunger data are only approximately correct, and even trends are uncertain. But this does not justify data nihilism; for example, there is strong evidence, from multiple sources, that undernourishment is excessive in India (Sainath, 1996; Black et al., 2008) and in parts of sub-Saharan Africa. 


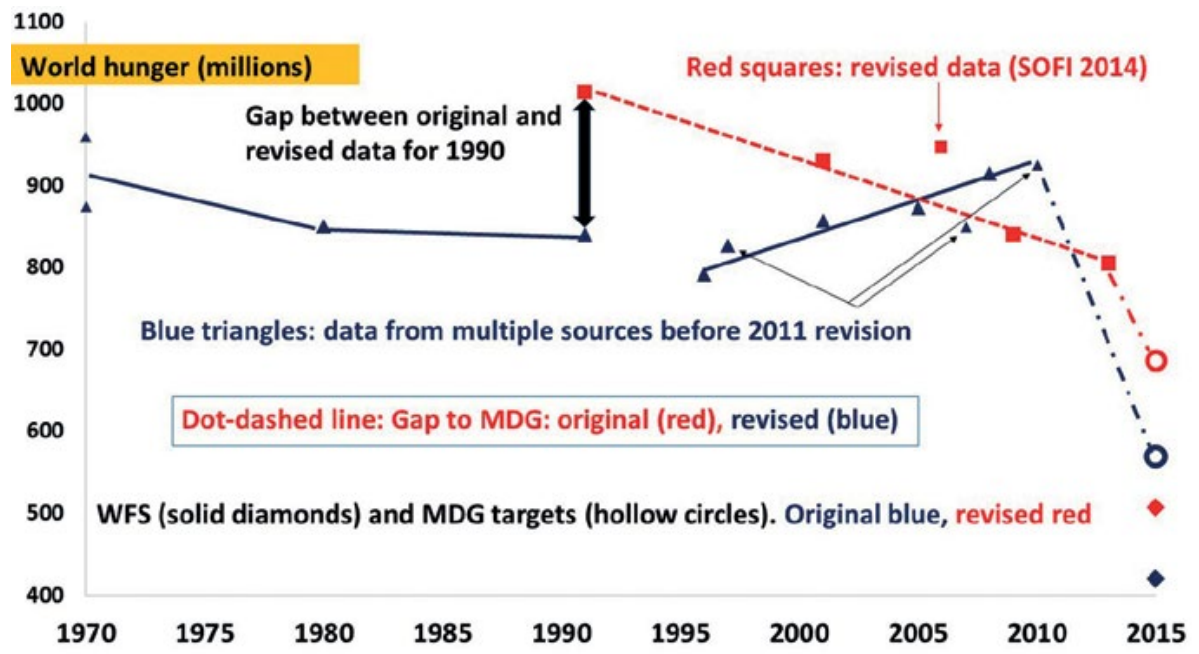

\section{Figure 14.1. World hunger (millions) and 2015 hunger targets, 1990-2015.}

The blue triangles show global hunger points using data reported by the FAO until 2010. The red squares refer to FAO data reported in 2014. The data points reported in SOFI 2012 and 2013 are similar to these, but not shown for simplicity. Focussing on the blue points a decline in hunger between 1970 and 1996 is evident, followed by an obvious increase until 2010, the last year for which data using the pre-2011 method are available. The spike in hunger to over a billion in 2009 (reported in SOFI 2009 and 2010) is not shown, for simplicity. In contrast, the red squares show a generally declining trend between 1990 and 2013, including the period of rising global food prices.

In addition, four hunger targets are shown for 2015. The hollow blue circle $(568 \mathrm{~m})$ shows the original MDG target (converted from a percentage). Its revision $(687 \mathrm{~m})$ is shown as a solid red circle. The revised trend looks far more encouraging, but its credibility is uncertain. The solid blue diamond (420 m) shows the original WFS target. Its revision $(507 \mathrm{~m})$ is shown as a solid red diamond. The revised trend looks far more encouraging, but its credibility is uncertain Note, too, that the revised estimate of hunger in 1990 (1.01 billion) is substantially higher than previously reported for 1970 (920 million). This implies (implausibly) either that hunger increased between 1970 and 1990, the heyday of the Green Revolution (see figure 14.2), or that the percentage of the world's population who were hungry in 1970 was closer to 30 per cent than the 25 per cent it was then thought to be. A third variant is that the revised hunger estimates are wrong. World population data were taken from FAOSTAT.

Source: Author's work, from raw FAO data (not previously published).

\section{Persistent Hunger: Rising Concerns, Possible Solutions}

One hundred million hungry people is immense; it should be an unacceptably large number in today's world. Yet, the actual number of people deprived of sufficient macronutrients for health or economic productivity is at least seven times as large, even using the more optimistic FAO measure. This is an abysmal state of affairs for the world's ultra-poor, though it seems unlikely that few of them fully realise this, in part from a lack of the necessary pedagogical components 
of the oppressed (Freire, 1970). In addition, up to two billion additional people suffer micronutrient deficiencies, especially iron and zinc. Iron, especially, is vital for stamina, learning and earning capacity. Chronic undernutrition of both macro- and micronutrients also increases the risk of chronic illnesses, occurring at relatively young ages, should undernourished infants survive into mid- or later life (Victora et al., 2008).

Now, after several decades of widespread complacency about global food security, academic interest is returning, not only in hunger but also in the issue of limits to growth more broadly (Turner, 2008; Ehrlich and Ehrlich, 2013; Motesharrei et al., 2014). Not only climate change but also other forms of 'planetary overload' (as Tony McMichael (1993) called it) deepen the challenge of sufficient and sustainable food production (see Box 14.2). Agricultural intensification, particularly of livestock, is only a partial solution. While it can help preserve biodiversity-rich ecosystems, such as forests (Garnett et al., 2013), intensive animal farming still requires extensive inputs, particularly of feed and shipping. Intensive animal farming can also generate novel and virulent strains of infectious diseases, affecting humans and animals alike (Liverani et al., 2013). Intensive crop production (monoculture) has its own problems, and in any case is already used widely. Rice intensification has been promoted for more than a decade, by some, as a miracle method of raising more food on a given area, but with little compelling evidence (Sheehy et al., 2004). ${ }^{3}$ Similarly, genetically modified crops promise far more for food security than has been delivered to date.

In addition, but discussed inadequately in recent decades by most agricultural scholars, including the FAO, high rates of human population growth continue in many regions that are poor and already famine struck, such as Niger (Royal Society, 2012).

3 However, persistent reports from India continue to intrigue (e.g. www.agriculturesnetwork.org/resources/ extra/bihar-sri, accessed 12 February 2015). 


\section{Box 14.2 Limits to growth}

\section{Energy}

The steep rise in the price of energy from about 2005 to late 2014 is due mainly to falling supplies of the most accessible, high-quality forms of fossil fuel (Murray and King, 2012). The sustained high price of energy early in that period made many forms of unconventional fossil fuel economically feasible, at least for a period. But such energy is no bargain, and its combustion will use up the remaining 'carbon budget', risking critical climate change (Hansen et al., 2013). In late 2014, in a little-foreseen development, Saudi Arabia flooded the market with oil at a price at which it appears only it can sustain for long. Seen by some as a tactic to hurt Iran and Russia (Cooper, 2014), and by others as a means to cripple its high-cost competitors such as oil from fracking or tar sands (Moran, 2014), few if any commentators argue that such low prices can be sustained for many years (Heinberg, 2014). Optimists hope that by the time oil prices again rise substantially, the price of renewables will be so low as to also drive energy from 'tight' oil from the market.

\section{Other metals}

Similar to oil, the most accessible forms have been preferentially accessed. What remains, whether of copper, gold, lead and nickel is in a similar position (Michaux, 2014).

\section{Phosphorus}

This element must be mined or recycled. Reserves are now concentrated in only three countries, and its price is rising. Peak phosphorus may occur before 2050 (Cordell et al., 2009).

\section{Climate change}

Though not conventionally considered a form of limit to growth, climate change is, for two reasons: (i) the capacity of the Earth system to absorb waste gases is limited; consequently, waste gas concentration is rising; (ii) climate change will limit real economic growth, such as is the case with Typhoon Haiyan, which devastated the Filipino city of Tacloban in 2013 (Vidal, 2013).

\section{Food fuels}

The rising cost of energy has stimulated alternative liquid fuels made from crops, which could be used to supply food; especially maize, sugarcane and palm oil. The potential of numerous other crops for ethanol and other biofuels is being explored (de Vries et al., 2010). Already, about 40 per cent of US maize is used for fuel, not food.

\section{Crop yield limits}

All animal and plant species have limits to height and weight. The annual rate of increase of many crop yields, in many countries, is now flattening, including in China, India, the USA and Europe (Grassini et al., 2011; Ray et al., 2013). 


\section{Fertile land and water}

Diminishing tracts of potentially fertile land exist, though many forest areas are inhabited by Indigenous peoples. Such areas provide vital regulating and cultural ecosystem services and have inherent existence value. We surely destroy them at our peril. Water scarcity is increasing, including from aquifer depletion.

\section{Diminishing returns to additional complexity}

The Collapse of Complex Societies (Tainter, 1988) suggests that human societies, like other organisms, have an optimal size for optimal function. Some megacities have exceeded this optimum.

\section{Increased Vegetarianism to Ameliorate Global Hunger?}

In 1971, Diet for a Small Planet (Lappé and Collins, 1971) pointed out that a substantial fraction of grain that could be fed to humans was instead used to feed animals to supply meat. Because animals convert plants to flesh inefficiently, advocates for vegetarianism argue that if this edible food were ingested by people, ample food would exist, even as the population rises. Since 1971, the 'feed conversion' rates of animals grown for meat have greatly improved (Godfray et al., 2010), due in part to more crowding, reduced exercise and the selection of rapidly growing breeds of animal. However, the nutritional properties of such animals has probably declined, due, in part, to their decreased exercise and, perhaps, a less favourable composition of fatty acids in their diet. Undoubtedly, though, the grain and soy animals eat would feed more people if ingested directly by humans.

There are two main reasons why advocates of complete, or even predominant, vegetarianism meet limited success, globally. First, complete vegetarianism is often neither culturally preferred nor ecologically possible, particularly in cultures traditionally based on pastoralism, hunting or fishing. In such regions, where crop growing is often difficult, animals convert indigestible grass and scraps, to humans, adding to the total human food supply.

The second reason why complete vegetarianism is impossible, from an anthropocentric perspective, is nutritional. Complete vegetarianism (even with synthetic vitamin B12 supplementation) is physiologically inadequate for many people due to low absorption of iron and probably zinc. Low iron levels are especially likely in vegetarians who lack the gene for haemochromatosis, a condition that enhances iron absorption (Naugler, 2008). Other genes and cultural habits (such as certain spices) that have a similar function may also exist. 
However, perhaps one to two billion people eat more animal products, especially meat and dairy products, than is needed for good nutrition. Lowering the ingestion by this population, especially of red meat from digastric mammals that emit methane, will improve their health and slow the rate of greenhouse gas accumulation (McMichael et al., 2007). Increased vegetarianism by so many people would also reduce pressure on global food supplies.

The argument that the cause of global hunger cannot be solved simply by more food production (Carolan, 2012, Garnett et al., 2013), including agricultural intensification, is correct. Improved social determinants of food security are also needed. Such 'productionist' views appear to finally be becoming less influential. For example, while the main FAO (2013) report for The State of Food and Agriculture stresses investment in farmers and in agriculture as the main solution to hunger, and is silent on increased vegetarianism and even on food redistribution, it does discuss the need for a 'food systems' approach to underand overnutrition. Also, though the report does not mention that treating parasites and other chronic illnesses that rob or cost nutrients will improve nutrition, it does mention improved sanitation, hand washing and other ways to improve public health.

\section{Reduced Food Waste, Including of Offal}

Recent FAO reports also give increasing attention to food waste, whether pre-harvest, post-harvest or pre- or post-purchase (Institution of Mechanical Engineers, 2013). The custom of eating offal has all but vanished among most affluent populations, though not in China; less waste of offal would also extend food supplies (and possibly benefit health).

\section{Critics of the Green Revolution}

Arguments in favour of greater global sharing of food resources are made by prominent critics of the Green Revolution, such as the physicist Vandana Shiva (1991). However, Shiva's conceptualisation of this agricultural technology seems inseparable from that of the unfair social structures of many of the societies that have employed it. It is true that industrialised agriculture associated with the Green Revolution favoured large over small farmers, and in many cases helped to perpetuate or enhance inequality. But, it is overly simplistic to blame an agricultural technology, operated and controlled by humans, for the inequality. 
There are many interlocking reasons for inequality and poverty, and it is simplistic to blame only the new crop varieties or pesticides. The criticism of Shiva and others would be more accurate if directed towards the societies that implement unfair versions of the Green Revolution.

\section{Food Redistribution}

The appeals for a fairer distribution of food have, to date, not been very successful. While excessive inequality cannot be sustained indefinitely in either human society or many animal groups, all human and many animal groups are, in fact, characterised by numerous forms of inequality, whether of status, power, experience, strength or ability. The reduction of human inequality on a scale sufficient to abolish hunger completely is certainly desirable, at least to egalitarians who subscribe to the principle of social justice, but it is currently utopian.

Despite the uncertainty concerning hunger data, there was, until 2012, consensus that the proportion of global hunger (and the absolute number) fell substantially between about 1970 and 1990, the heyday of the Green Revolution, when supplies of grain and soy per person were rising sharply (see Figure 14.2). This reduction in hunger probably had more to do with rising food production (thus endorsing support for 'productionism') and falling food prices than with deliberate redistribution policies, although the ideological competition of the Cold War probably did encourage more international cooperation than the subsequent period of neoliberalism (Butler, 2000b). A virtuous feedback may have also developed (a component needed to improve the pedagogy of the oppressed) (Freire, 1970), in which better-nourished people organised to demand other factors that contributed to increased prosperity, including education, lower fertility and greater human rights. That success in hunger reduction appears to form the basis for today's dominant strategies to reduce hunger, but this approach is influenced by denial, selective data interpretation and think tanks funded by and loyal to fossil fuel industries and other vested interests. 


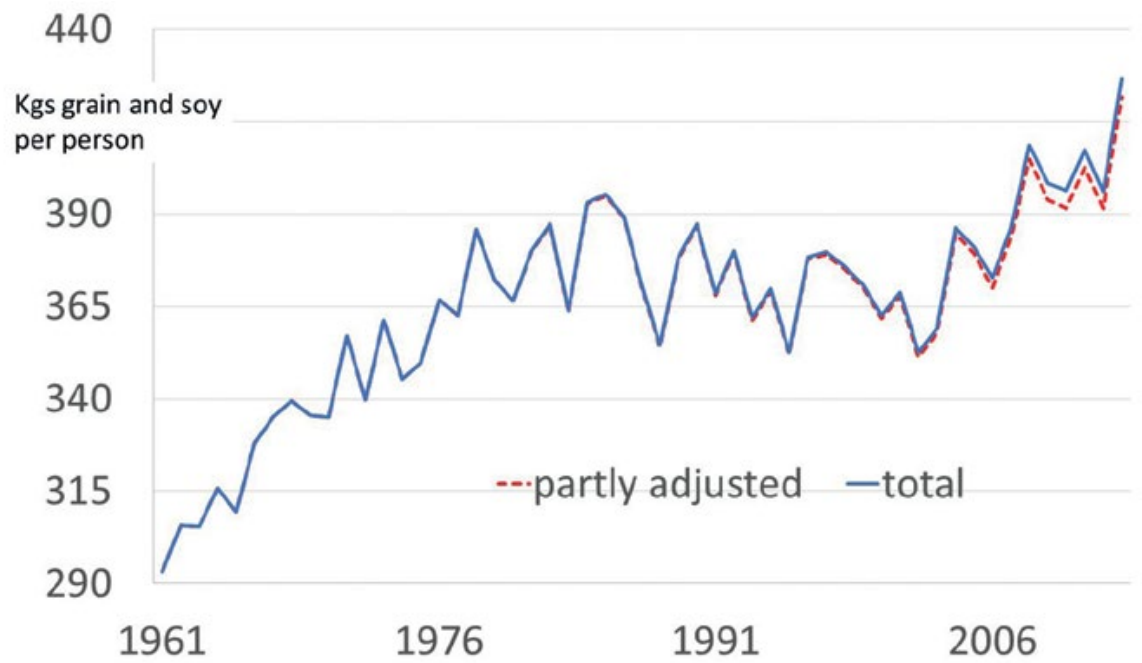

Figure 14.2. Global per capita production of grain and soy, 1961-2013, total and partly adjusted for ethanol from US maize.

Grain and soy are both durable and transportable. Rice is fed mostly to humans, but other grains, especially maize, are used both for animal feed and biofuels. Almost all soy (reported as much as 97 per cent) is fed to animals (Steinfield et al., p. 46). In 2013 the production of grain and soy reached a new record. Claims that food production per person has recently been at all-time highs do not tell the whole story, due to the lack of easily accessible data adjusted for (animal) feed and for 'fuel' foods. However, the production reported in 2013 is striking, and it may be a record, even after accounting for feed and fuel. Importantly, however, the diversion of so much food away from human mouths does not mean that hunger for the poorest 700 million is overcome.

Source: Author's work, from raw FAO data (not previously published).

\section{Climate Change, Food, Security and More Wishful Thinking}

There is increasing scientific doubt that an average global temperature increase due to anthropogenic climate change can be limited to $2^{\circ} \mathrm{C}$ (Peters et al., 2013). The current warming already appears to be harming crop production (Butler, 2014a, 2014b), and the World Bank (2012) recently added its weight to warnings that a rise of $4^{\circ} \mathrm{C}$ would have profound and adverse consequences for agricultural production and undernutrition.

Despite these warnings, the rapidly increasing scientific literature about agriculture, nutrition and climate change remains conservative (Butler, 2010, 2014 b). For example, the fourth report of the Intergovernmental Panel on Climate Change (IPCC) concluded that climate change would generate a modest increase in global food production, provided that the global average temperature increase did not exceed $3^{\circ} \mathrm{C}$ (Easterling et al., 2007). This conclusion was based partly 
on an optimistic assessment of the benefits to crops from the carbon fertilisation effect (CFE), ${ }^{4}$ and partly on a failure to account properly for extreme weather events and excessive optimism concerning adaptation to climate change. There is also a long tradition of unrealistic optimism by the FAO concerning climate change and food security (Goldsmith and Hildyard, 1991).

The 2007 IPCC report also has estimates for hunger in 2080 (in the absence of climate change) that appear wildly optimistic. Scenarios are characterised by general economic development, with seeming dismissal or incomprehension about the feedbacks discussed in this chapter and by many others. Even the worst scenario shows a marked improvement compared to 2010, while the three best scenarios predicted that macronutrient hunger would almost vanish (Easterling et al., 2007). The agricultural chapter of the Fifth IPCC Assessment, published as this chapter was being completed, is less optimistic, especially if the average level of warming reaches beyond 3 degrees (Porter et al., 2014).

There is also insufficient recognition, including among health workers, of the potential for climate change to trigger systemic, interacting, socially propagated 'tertiary' adverse effects, on a sufficient scale to endanger civilisation (Butler, 2014c). Such consequences include conflict, large-scale migration and impaired global governance. However, on the other hand, there is a long history of recognition, dating at least to the birth of the United Nations, including the FAO and its founding Director General, Boyd Orr, of the relationship between food insecurity and conflict (Staples, 2003). Any significant deterioration in regional or global food security has consequences for conflict and governance.

Excessive hope also affects the recent estimates of food production For example, Josette Sheeran, head of the World Food Programme in 2011, claimed that food production per person was at a record high (Sheeran, 2011). However, the data she (and many others) use to support such claims fails to account for food-crop diversion to biofuels, such as 40 per cent of US maize and 98 per cent of Brazilian sugarcane. A substantial number of other crops are also used for biofuels, and these 'food fuels' should not be counted as crops for human consumption. From 2011 until very recently, the rise in food prices also suggests that food production (excluding biofuels) per person has further declined (Butler, 2014b). If food per person is really so abundant, why have global food prices been so persistently near record highs? Note, however, that at the time of revising this chapter (March 2015), food prices had fallen (though are still well above

4 The 2007 IPCC food chapter included a detailed discussion of the CFE literature, without a conclusion. In my view, and that of other critics (Long et al., 2006) sufficient evidence then existed then to conclude that the CFE was weaker than earlier believed, especially for C4 crops such as maize. However, I have not identified any authors who have specifically commented on this with regard to the IPCC. 
levels earlier this century), and, as figure 14.2 shows, grain and soy may have reached a record high in 2013, even accounting for biofuels. Time will tell if this production can be sustained and if food prices continue to fall.

\section{The Distracting Debate between Advocates for Consumption and Population}

In 1970, Norman Borlaug, 'father' of the Green Revolution, was awarded the Nobel Prize. His acceptance speech warned in part:

There can be no permanent progress in the battle against hunger until the agencies that fight for increased food production and those that fight for population control unite in a common effort. (Borlaug, 1970)

In 1966, a famine was emerging in the chronically impoverished, caste-ridden northern Indian state of Bihar. Its ecological causes included drought and, in some parts, floods. At that time, there was little extraction of groundwater (contaminated by naturally occurring arsenic) using tube wells. In response, US State officials recommended large shipments of American grain as relief aid. President Johnson agreed, on condition that India's family planning programme be strengthened (Califano, 1981). This was the time of maximum concern about global population growth, which peaked in 1968 at 2.1 per cent per annum. Paul Ehrlich's book, The Population Bomb, was a major bestseller, globally.

Yet, exactly at this time (but then underappreciated), global food supplies per person were rising steeply, due to the Green Revolution (see Figure 14.2), achieved entirely without genetic modification, by selective plant breeding, economies of scale and the extensive use of fossil fuel (including to manufacture pesticides). This allowed far more food to be grown in a given area, provided there was adequate fertiliser and water. It thus helped to preserve biodiversity. I am unaware of any scholar, including Shiva, who proposes how the widespread famines perceived by many as plausible in the 1970s could have been averted without some form of the Green Revolution.

In the following two decades, food supplies rose spectacularly on a per person basis (see Figure 14.2). World hunger also declined, both proportionally and in absolute terms. While a few famines occurred from 1970 to 2000, their scale was modest compared to what had been feared.

Until Reagan became US president, his predecessors, from Eisenhower to Carter, had recognised, to varying degrees, like Borlaug, that high population growth posed a risk to global food and other forms of human security (Butler, 2004). These presidents supported not only the Green Revolution but also policies 
(direct and indirect) that slowed global population growth. In 1984, Reagan broke this consensus, declaring that the importance of human population size had been 'vastly exaggerated' (Finkle and Crane, 1985). Since then, on the Right, neoliberal supporters and their policies have downplayed the importance of population, while critics on the Left have, unhelpfully, generally argued that consumption is far more important (Monbiot, 2008).

In reality, both matter. Population matters: principally in rich countries, where too many of us consume too much; our collective footprint is the main cause of planetary overload (McMichael and Butler, 2011). High population size and growth in poor countries also matters. This is not because of the contribution of the global poor to the global 'footprint', but because it helps trap such populations in poverty (Campbell et al., 2007). Finally, population in poor countries matters because their elevation from poverty (if it ever occurs) will increase their environmental footprint greatly, unless they rely almost exclusively on solar and other environmentally preserving technologies, including the recycling of phosphate.

\section{Conclusion}

This chapter has a very broad scope. Lack of space prevents in-depth discussion of many issues it raises, for which I apologise. Collectively, limits to growth, including climate change, are generating a slow-moving, global, intergenerational crisis. I believe that our collective political leadership is in denial, demonstrated, for example, by the embarrassing failure of the Rio +20 summit in 2012, which was attended by few leaders of wealthy countries.

For decades, agricultural companies and their neoliberal, techno-optimistic supporters have claimed that genetic manipulation is the best means to trigger a new agricultural revolution. But, little progress has been made, at least relative to the required challenge, and long-predicted (Steinbrecker, 1996) adverse effects increasingly are documented, including pesticide-resistant weeds (Bonny, 2011) and harm to health (Séralini et al., 2011). A Green Revolution could enhance food production in Africa (Ejeta, 2010), but this is made much more challenging by the high price of energy. As important as are arguments for more food, ways to alter the determinants of fertility so as to increase child survival and the demand for education and lower population growth are at least as urgent.

The moral compass of the global elite, cheered on by lobbyists and advertisers, has, in recent decades, been set to indulgence and selfishness, manifest not only by declining foreign aid by most rich countries but also by excessive consumerism during the 'cornucopian enchantment' (Butler, 2007). This decay has also affected government and academia, in ways that have inhibited public 
awareness of these larger risks. Continuation of this behaviour will lead either to the managed retreat of civilisation or to its disorderly rout (Ehrlich and Ehrlich, 2013).

The most important academic response to the gathering crisis of food and governance is not to call for more agricultural investment. While necessary, this is insufficient. Instead, multidisciplinary recognition of these fundamental, interlinked crises is required, along with planetary mobilisation on the scale of a global war, to transform the entire industrial system (Ehrlich and Ehrlich, 2013). This task is seemingly impossible, but its scale is less forbidding if this task is considered incrementally. To start, policymakers and politicians need to show courageous leadership, including challenging what could be called the 'other Rome Consensus'; that is, the belief that all is well and that hunger will gradually decline if we follow business as usual.

One step is to change the focus from the effort to increase supply in order to meet wants and needs, to instead develop ways in which humanity can slow resource consumption in both the near and long-term future, including by slowing population growth by providing determinants of lower fertility using human rights-based approaches, especially better education for girls and women (Campbell et al., 2007). Non-government organisations and civil society, such as Climate Justice, the foundation established by Mary Robinson, are also vital.

\section{References}

André, C. \& Platteau, J.-P., 1998. Land relations under unbearable stress: Rwanda caught in the Malthusian trap. Journal of Economic Behavior and Organization 34, 1-47.

Barrett, C.B. 2010. Measuring food insecurity. Science 327, 325-8.

Black, R.E., Allen, L.H., Bhutta, Z.A., Caulfield, L.E., de Onis, M., Ezzati, M., et al. 2008. Maternal and child undernutrition: global and regional exposures and health consequences. The Lancet 371, 243-60.

Bonny, S. 2011. Herbicide-tolerant transgenic soybean over 15 years of cultivation: pesticide use, weed resistance, and some economic issues. The case of the USA. Sustainability 3, 1302-22.

Borlaug, N. 1970. Nobel Prize Acceptance Speech. Available at: www.nobelprize. org/nobel_prizes/peace/laureates/1970/borlaug-acceptance.html, accessed 20 April 2014. 
Brown, L.R., 2012. World in serious trouble on food front Earth Policy Institute, www.earth-policy.org/plan_b_updates/2012/update104, accessed 22 March 2015.

Butler CD. 2000a. Entrapment: global ecological and/or local demographic? Reflections upon reading the BMJ's 'six billion day' special issue. Ecosystem Health 2000;6(3):171-80.

Butler, C.D. 2000b. Inequality, global change and the sustainability of civilisation. Global Change and Human Health 1, 156-72.

Butler, C.D. 2004. Human carrying capacity and human health. Public Library of Science Medicine 1, 192-4.

Butler, C.D. \& Friel, S. 2006. Time to regenerate: ecosystems and health promotion. Public Library of Science Medicine 3, e394.

Butler, C.D. 2007. Globalisation, population, ecology and conflict. Health Promotion Journal of Australia 18, 87-91.

Butler, C.D. 2010. Climate change, crop yields, and the future. SCN News $38,18-25$.

Butler, C.D. 2012. Infectious disease emergence and global change: thinking systemically in a shrinking world. Infectious Diseases of Poverty 1, 5.

Butler, C.D. 2014a. Famine, hunger, society and climate change. In: Butler, C.D. (ed.) Climate Change and Global Health. CABI, Wallingford, UK, 124-34. Available (open access) at: www.cabi.org/openresources/42659, accessed 5 January 2015.

Butler, C.D. 2014b. Food, water and climate change. In: Freedman, B. (ed.) Global Environmental Change. Springer, Netherlands, 630-47.

Butler, C.D. (ed.) 2014c. Climate Change and Global Health. CABI, Wallingford, UK.

Butler, C.D. (2015). Revised hunger estimates accelerate apparent progress towards the MDG hunger target Global Food Security 5(6): 19-24.

Califano, J. 1981. Governing America. Simon and Schuster, New York, USA.

Campbell, M., Cleland, J., Ezeh, A. \& Prata, N. 2007. Return of the population growth factor. Science 315, 1501-2.

Carolan, M. 2012. The food and human security index: rethinking food security and growth. International Journal of Sociology of Agriculture and Food 19, 176-200. 
Cooper, A.S., 2015. Why would the Saudis deliberately crash the oil markets? Simple: to undermine Tehran. Foreign Policy foreignpolicy.com/2014/12/18/ why-would-the-saudis-crash-oil-markets-iran/, accessed 30 March 2015.

Cordell, D., Drangert, J.-O. \& White, S. 2009. The story of phosphorus: global food security and food for thought. Global Environmental Change 19, 292-305.

de Vries, S.C., van de Ven, G.W.J., van Ittersum, M.K. \& Giller, K.E. 2010. Resource use efficiency and environmental performance of nine major biofuel crops, processed by first-generation conversion techniques. Biomass and Bioenergy 34, 588-601.

Easterling, W.E., Aggarwal, P.K., Batima, P., Brander, K.M., Erda, L., Howden, S.M., et al. 2007. Food, fibre and forest products. In: Parry, M.L., Canziani, O.F., Palutikof, J.P., van der Linden, P. \& Hanson, C.E. (eds) Climate Change 2007: Impacts, Adaptation and Vulnerability. Contribution of Working Group II to the Fourth Assessment Report of the Intergovernmental Panel on Climate Change. Cambridge University Press, Cambridge, UK, 273-313.

Ehrlich, P.R., 1968. The Population Bomb. Ballantyne, London, UK.

Ehrlich, P.R. \& Ehrlich, A.H. 2013. Can a collapse of global civilization be avoided? Proceedings of the Royal Society B: Biological Sciences 280.

Ejeta, G. 2010. African Green Revolution needn't be a mirage. Science 327, 831-2.

FAO (Food and Agricultural Organization) 2012. The State of Food Insecurity in the World 2012. FAO, Rome, Italy.

FAO 2013. The State of Food and Agriculture. FAO, Rome, Italy.

FAO 2014. The State of Food Insecurity in the World 2014. FAO, Rome, Italy.

Finkle, J.L. \& Crane, B. 1985. Ideology and politics at Mexico City: the United States at the 1984 International Conference on Population. Population and Development Review 11, 1-28.

Freire, P., 1970. Pedagogy of the Oppressed. Herder and Herder, New York, USA; 40th anniversary edition, Continuum, www.pedagogyoftheoppressed.com, accessed 30 March 2015.

Garnett, T., Appleby, M.C., Balmford, A., Bateman, I.J., Benton, T.G., Bloomer, P., et al. 2013. Sustainable intensification in agriculture: premises and policies. Science 341, 33-4. 
Godfray, H.C.J., Beddington, J.R., Crute, I.R., Haddad, L., Lawrence, D., Muir, J.F., et al. 2010. Food security: the challenge of feeding 9 billion people. Science 327, 812-8.

Goldsmith, E. \& Hildyard, N. 1991. World agriculture: toward 2000, FAO's plan to feed the world. The Ecologist 21, 81-92.

Grassini, P., Thorburn, J., Burr, C. \& Cassman, K.G. 2011. High-yield irrigated maize in the Western U.S. corn belt: I. On-farm yield, yield potential, and impact of agronomic practices. Field Crops Research 120, 142-52.

Grove, R.H., 1998. Global impact of the 1789-93 El Niño. Nature 393, 318-9.

Gunn, G.C. 2011. The Great Vietnamese Famine of 1944-45 revisited. Available at: naosite.lb.nagasaki-u.ac.jp/dspace/bitstream/10069/25151/1/toasia52_81. pdf, accessed 20 April 2014.

Hansen, J., Kharecha, P., Sato, M., Masson-Delmotte, V., Ackerman, F., Beerling, D.J., et al. 2013. Assessing 'dangerous climate change': required reduction of carbon emissions to protect young people, future generations and nature. PLOS ONE 8, e81648.

Heinberg, R. 2014. The oil price crash of 2014. Post Carbon Institute. www.postcarbon.org/the-oil-price-crash-of-2014/ March 30, 2015.

Horton, R. 2008. Maternal and child undernutrition: an urgent opportunity. The Lancet 371, 179.

Institution of Mechanical Engineers 2013. Global Food; Waste Not, Want Not. www.imeche.org/knowledge/themes/environment/global-food, accessed 30 March 2015.

Kelley, C.P., Mohtadi, S., Cane, M.A., Seager, R. \& Kushnir, Y., 2015. Climate change in the Fertile Crescent and implications of the recent Syrian drought. Proceedings of the National Academy of Sciences (USA)112: 3241-6.

Lappé, F.M. \& Collins, J. 1971. Diet for a Small Planet. Institute for Food and Development Policy, San Francisco, California, USA.

Lappé, F.M., Clapp, J., Anderson, M., Lockwood, R., Forster, T., Nierenberg, D., et al. 2013. Framing Hunger. Small Planet Institute, Cambridge, Massachusetts, USA, WhyHunger, New York City, USA, Institute for Agriculture and Trade Policy, Minneapolis, Minnesota, USA, Food \& Water Watch, Washington, DC, USA, Canada, Ottawa, ETC Group, Canada, Terra Nuova, Rome, Italy. 
Liverani, M., Waage, J., Barnett, T., Pfeiffer, D.U., Rushton, J., Rudge, J.W., et al. 2013. Understanding and managing zoonotic risk in the new livestock industries. Environmental Health Perspectives 121, 873-7.

Long, S.P., Ainsworth, E.A., Leakey, A.D.B., Nösberger, J. \& Ort, D.R., 2006. Food for thought: lower-than-expected crop yield stimulation with rising $\mathrm{CO}_{2}$ concentrations. Science 312, 1918-21.

Mallory, W.H. 1926. China: Land of Famine. American Geographical Society, New York, USA.

McMichael, A.J. 1993. Planetary Overload. Global Environmental Change and the Health of the Human Species. Cambridge University Press, Cambridge, UK.

McMichael, A.J. \& Butler, C.D. 2011. Promoting global population health while constraining the environmental footprint. Annual Review of Public Health 32, 179-97.

McMichael, A.J., Powles, J., Butler, C.D. \& Uauy, R. 2007. Food, livestock production, energy, climate change and health. The Lancet 370, 1253-63.

McMichael A.J., Butler C.D. \& Dixon, J. 2015. Climate change, food systems and population health risks in their eco-social context Public Health. doi: dx.doi. org/10.1016/j.puhe.2014.11.013.

Maxwell, D., Haan, N., Gelsdorf, K. \& Dawe, D. 2012. The 2011-12 famine in Somalia: introduction to the special edition. Global Food Security 1, 1-4.

Michaux, S., 2014. The coming radical change in mining practice. In: J. Goldie and K. Betts (eds.), Sustainable Futures: Linking Population, Resources and the Environment. CSIRO Press, Collingwood, Vic, Australia, 73-84.

Monbiot, G. 2008. Population growth is a threat. But it pales against the greed of the rich. The Guardian. www.theguardian.com/commentisfree/2008/jan/29/ politics.greenpolitics, accessed 30 March 2015.

Moran, M. 2014. Is Saudi Arabia trying to cripple American fracking? Foreign Policy. foreignpolicy.com/2014/12/23/is-saudi-arabia-trying-to-crippleamerican-fracking-oil-iran/, accessed 30 March 2015.

Motesharrei, S., Rivas, J. \& Kalnay, E. 2014. Human and nature dynamics (HANDY): modeling inequality and use of resources in the collapse or sustainability of societies. Ecological Economics 101, 90-102.

Murray, J. \& King, D. 2012. Climate policy: oil's tipping point has passed. Nature 481, 433-5. 
Naugler, C. 2008. Hemochromatosis: a Neolithic adaptation to cereal grain diets. Medical Hypotheses 70, 691-2.

Peters, G.P., Andrew, R.M., Boden, T., Canadell, J.G., Ciais, P., Quéré, C.L., et al. 2013. The challenge to keep global warming below $2^{\circ} \mathrm{C}$. Nature Climate Change 3, 4-6.

Pogge, T. 2004. The first United Nations Millennium Development Goal: a cause for celebration? Journal of Human Development 5, 377-97.

Porter, J.R., Xie, L., Challinor, A.J., Cochrane, K., Howden, S.M., Iqbal, M.M., et al. 2014. Food security and food production systems. In: Climate Change 2014: Impacts, Adaptation, and Vulnerability. Part A: Global and Sectoral Aspects. Contribution of Working Group II to the Fifth Assessment Report of the Intergovernmental Panel on Climate Change [Field, C.B., Barros, V.R., Dokken, D.J., Mach, K.J., Mastrandrea, M.D., Bilir, T.E., Chatterjee, M., Ebi, K.L., Estrada, Y.O., Genova, R.C., Girma, B., Kissel, E.S., Levy, A.N., MacCracken, S., Mastrandrea, P.R. \& White, L.L. (eds)]. Cambridge University Press, Cambridge, United Kingdom and New York, NY, USA, 485-533.

Rahman, M. 2006. Indian leader likens caste system to apartheid regime. The Guardian, 28 December 2006. www.theguardian.com/world/2006/ dec/28/india.mainsection, accessed 30 March 2015.

Ray, D.K., Mueller, N.D., West, P.C. \& Foley, J.A. 2013. Yield trends are insufficient to double global crop production by 2050. PLOS ONE 8, e66428.

Royal Society 2012. People and Planet. The Royal Society, London, UK.

Sainath, P. 1996. Everybody Loves a Good Drought: Stories from India's Poorest Districts. Penguin, New Delhi, India.

Sen A.K. 1981 Poverty and Famines: An Essay on Entitlement and Deprivation. Clarendon Press, Oxford, UK, New Delhi, India.

Séralini, G.-E., Mesnage, R., Clair, E., Gress, S., de Vendômois, J. \& Cellier, D. 2011. Genetically modified crops safety assessments: present limits and possible improvements. Environmental Sciences Europe 23, 1-10.

Sheehy, J.E., Peng, S., Dobermann, A., Mitchell, P.L., Ferrera, A., Yang, J., et al. 2004. Fantastic yields in the system of rice intensification: fact or fallacy? Field Crops Research 88, 1-8.

Sheeran, J. 2011. Preventing hunger: sustainability not aid. Nature 479, 469-70.

Shiva, V. 1991. The Violence of the Green Revolution. Third World Agriculture, Ecology and Politics. Third World Network and with ZED Books, London, UK. 
Staples, A.L.S. 2003. To win the peace: the Food and Agriculture Organization, Sir John Boyd Orr, and the World Food Board proposals. Peace \& Change $28,495-523$.

Steinbrecker, R. 1996. From green to gene evolution. The environmental risks of genetically engineered crops. The Ecologist 26, 273-81.

Steinfeld, H., Gerber, P., Wassenaar, T., Castel, V., Rosales, M. \& de Haan, C., 2006. Livestock's Long Shadow, FAO, Rome, Italy.

Tainter, J.A. 1988. The Collapse of Complex Societies. Cambridge University Press, Cambridge, UK.

Turner, G.M. 2008. A comparison of the limits to growth with 30 years of reality. Global Environmental Change 18, 397-411.

Victora, C.G., Adair, L., Fall, C., Hallal, P.C., Martorell, R., Richter, L., et al. 2008. Maternal and child undernutrition 2: maternal and child undernutrition: consequences for adult health and human capital. The Lancet 371, 340-57.

Vidal, J. 2013. Typhoon Haiyan: what really alarms Filipinos is the rich world ignoring climate change. The Guardian. www.theguardian.com/ commentisfree/2013/nov/08/typhoon-haiyan-rich-ignore-climate-change, accessed 30 March 2015.

Wood, G.D.A. 2014. Tambora: The Eruption that Changed the World. Princeton University Press, Princeton, New Jersey, USA.

World Bank 2012. Turn Down the Heat: Why a 4 Degree Celsius Warmer World Must be Avoided. The World Bank, Washington, DC, USA. 
This text is taken from Health of People, Places And Planet:

Reflections based on Tony McMichael's four decades of contribution to epidemiological understanding, edited by Colin D. Butler, Jane Dixon and Anthony G. Capon, published 2015 by ANU Press, The Australian National University, Canberra, Australia. 